\title{
Reflection
}

\section{Teaching resilience through Russian literature}

\author{
Andrew D. Kaufman \\ Department of Slavic Languages and Literatures, University of Virginia, USA
}

When Lisa* applied to my course, 'Books Behind Bars: Life, Literature, and Leadership,' in which University of Virginia students lead discussions about Russian literature with incarcerated youth at Beaumont Juvenile Correctional Center, she and I both had high hopes for her success in the class. Her application was impressive. A highly intelligent, passionate, socially conscious UVa student who had participated in national reconciliation efforts in post-genocide Rwanda and spent time studying social conflict in Jerusalem, Lisa was seeking a class that would stretch her intellectually and emotionally, as well as feed her passion for social justice. Her one apprehension, she admitted, was that the Beaumont residents might reject her attempts to connect with them. But if she was able to build bonds of mutual understanding with perpetrators of genocide in Rwanda and Arab youth supporters of the Intifada in Israel, then surely she could find common ground with the young incarcerated men at Beaumont. Or so she thought. As did I. It turns out that we were both wrong.

And yet if, as the educational philosopher John Dewey said, 'failure is instructive,' then Lisa's experience in Books Behind Bars - and her capacity to reflect deeply on it and learn from it - was an instructional goldmine. And not just for her, either. For me, as well, and for all of us, really, who care deeply about the humanities and who believe in the power of a humanities education to affect personal and social change. What Lisa discovered in the course, and I relearned vicariously through her, is what leaders from all walks of life often cite - and a growing body of research corroborates ${ }^{1}$ - as one of the most important lessons any successful leader can learn: the value of resilience.

Often defined as the capacity to bounce back, to adapt and persevere in the face of adversity, resilience is also, I would add based on my experience with Books Behind Bars, the courage to hold onto one's ideals even after one has seen reality for what it is. ${ }^{2}$ No theme is more central to the Russian classics. The great Russian writers, who knew first-hand what it means to lose one's freedom, to be outsiders, to search for an ideal in a broken world, become strikingly relevant in Books Behind Bars. Fyodor Dostoevsky spent four years in a Siberian prison and was committed to four more years of mandatory military service for participating in a socialist revolutionary

\footnotetext{
* Names followed by an asterisk are pseudonyms, used to protect the identity of the UVa students and incarcerated youth participants in Books Behind Bars.

1. See, for instance: Intrator and Scribner (2007, pp. 131-154); Ledesma (2014); Patterson and Patterson (2001); Snyder (2013).

2. See, for instance: Henderson and Milstein (1996); Masten (2001); Masten et al. (1990); Rutter (1990, p. 181).
} 
circle, and that was only after receiving a last-minute reprieve from execution by firing squad. A little over a century later Alexander Solzhenitsyn was arrested for having criticized Stalin in private correspondence to a friend, and was sentenced to eight years in one of the worst prison camps in the 'Gulag.' Yet their writings continually remind us not only what human beings are, but what they can become. Both writers emerged from the hell of prison neither cynical nor embittered, but with a redoubled commitment to creating works of art that celebrate human excellence and the possibility of social justice amid the pain and injustice all around them.

And then there was Tolstoy, who was never incarcerated himself but who as a young man witnessed a public execution in Paris, lived through the European revolutions of 1848 and the first bloody Russian revolution of 1905. In the final decade of his life he was reading daily newspaper accounts about pogroms and violent workers' riots. He watched in horror as his country razed villages and destroyed non-Russian populations as part of their centuries-long effort to subjugate the Caucasus. Yet what counts is this: having lived through all that, he never lost his faith in human promise, in human possibility.

Holding onto one's highest ideals while acknowledging stark reality is a difficult balancing act, and few people do it very well. I've encountered some students and many adults over the years whose confrontations with life's harsh truths have turned them into narrow-minded pragmatists or even steely-eyed cynics. I myself have been tempted in that direction on more than one occasion - not least during my teaching of Books Behind Bars, where I often hear blood-curdling stories from residents, guards, and other longtime workers at the correctional center about the dysfunctional backgrounds and traumatic lives of those who end up at the facility. At Beaumont, young adults with a history of psychiatric illness, delinquent behaviors, economic disadvantage, impoverished family and social support, and little history of academic success live in a secure facility, often against their will. Even before they arrive at Beaumont, many of these incarcerated young men have lost their faith in the world and themselves, and in their ability to get their needs met without resorting to crime. Still, a handful of these youths manage to rise above their circumstances and, against the odds, find the motivation to change their lives.

I think, for instance, of Don*, a lanky, smart nineteen-year-old with the physical demeanor and resonant voice of a distinguished young statesman. As soon as he finished his two-year sentence for a 'dumb mistake,' as he refers to the night when he and a buddy stole a neighbor's car, he planned to go to college and study 'everything.' Don wants to be an ambassador someday - as he put it, 'an ambassador to others to help solve conflict in ways our previous governments never thought of.' During the end-ofsemester celebration he spoke on behalf of the residents, sharing what the Russian literature program meant to him:

This really opens up another window for us to look out of and a door for us to walk out of, shows us that we can do something like this in the near future, that this place is not the end for us. So this really shines a very bright light at the end of a dark path that we've gotten ourselves into.

Don's image of light in the darkness is one that recurs throughout Russian literature, and it nicely captures the sense of possibility experienced by many of the Beaumont residents who participate in Books Behind Bars. 'For an hour and a half a week I felt human,' says one young inmate. 'The whole Russian Literature Project, whenever I was in there, I didn't feel like I was incarcerated,' reports another. 'It made me feel less like a criminal ...' 
Reactions like these have been legion: 'I felt more free in Russian Literature, free to speak my mind, free to talk ... It got me used to communicating with people on a positive outlook, positive-based conversation ...'; 'They gave us a chance to participate in something'; 'It made us feel like we can - like we really were somebody ...'; 'It made me feel like I'm still in the world, in school ... like maybe one day I can go out there and be around college students in the free world.'

Indeed, inmates who participate in the Books Behind Bars program report an increased interest in attending college, and at least two former incarcerated participants who previously never had much interest in furthering their education are now actually enrolled in college. The program is also helping these guys with their moral development. '[The course] helped me understand messages that people have been trying to relay to me for my whole life,' says one inmate, 'but it would go in one ear and out the other. But when you actually break it down in the sense of a story, and you start putting it together, you really learn from it.'

A number of residents share how successfully tackling a subject as foreign and daunting as Russian literature has emboldened them to take other personal and intellectual risks. 'I learned that it ain't always a bad thing to try new things,' says one resident, '... if I'd have went against my better judgment then I would have never got in the class. I would have never tried this because it's not something that I ever had an interest in. So I would have just walked away from an experience that I really learned a lot from.'

These are the success stories, the tales of hope and achievement that have offered me the encouragement I have needed over the past six years to continue offering the Books Behind Bars course, despite the many logistical, bureaucratic, financial, and emotional challenges of running such a service learning program. These are also the kinds of stories that keep the UVa students motivated to come each week, prepared to lead discussions about literature and eager to deepen their relationships with the residents, in spite of the many practical, intellectual, and emotional obstacles they must contend with. Whether because of their youthful optimism or their awareness of previous success stories, the UVa students exhibit seemingly unshakeable confidence that their hard-won efforts to connect with these young men and engage them in meaningful conversation will eventually pay off. In most cases, they do.

In Lisa's case, they did not. No matter how hard she and her partner Jennifer* (UVa students work in pairs) tried, no matter how hard they worked or how creative they were in coming up with intriguing questions and activities to engage the residents, they were met, week after week, with resistance and even resentment. From the very first day, the residents they worked with seemed distracted, uninterested. They let Lisa and Jennifer know their likes (fighting and video games) and dislikes (women) and that the UVa students were just wasting their time in being there. 'You're putting a Bandaid on a bullet wound,' snarled Edward*, assuring Lisa and Jennifer that he expected to get nothing out of the program. Edward and James*, the other resident at his table, almost never read the stories, despite the UVa students' repeated pleading and assurance that the residents' contributions were deeply valued. 'Nah, you just don't get it,' James replied. 'We don't have it in us to get anything out of this.' During one meeting, Lisa and Jennifer invited the residents to imagine an alternative ending to a story - a perfectly appropriate activity given that the narrator himself offers multiple endings to his own story. Rather than viewing this as an opportunity for creative self-expression, the residents saw it as a provocation, and refused to play along. 'That's messing with other people's creation,' Edward insisted, and, folding his arms across his chest, he looked away and stared blankly across the room. For ten weeks this is roughly the way it went at that table. 
I often wondered if Edward and James weren't getting more out of the program than they let on. After all, they kept coming every week despite the fact that their participation was entirely voluntary and they could have left at any time. Were they there for a good laugh? To mess with the UVa students? Were we perhaps dealing with the sort of moral collapses Dostoevsky met while in Siberian prison and about whom he writes in Notes from the House of the Dead (1861 [2013])? Neither the UVa students nor I wanted to believe this, and there were indeed a few glimmers of hope to persuade us otherwise. During one meeting later in the semester, Edward opened up and talked about his arrest, in which he described taking the rap for a crime a friend committed. This was brought up as part of a conversation about a story by Varlam Shalamov, 'My First Tooth' (1982 [1995]), in which a young inmate at a Soviet labor camp intervenes on behalf of a fellow inmate who is being harassed by a guard. This act of moral courage earns the first inmate a cruel beating while standing naked in the snow, during which his tooth is knocked out. Had he made the right decision? Lisa and Jennifer asked the residents. 'Nope,' Edward insisted without hesitation. 'You've got to look out for yourself. He didn't have no business gettin' involved.' James nodded his head in agreement.

I happened to be sitting at the table that week, and watched as Lisa and Jennifer skillfully listened and prodded, offering their own views to stimulate further conversation, which stayed afloat for a few minutes and then eventually sank. I was heartened that the residents were willing to engage in such meaningful discussion, if only briefly, and that they showed at least some interest in the kind of moral reflection encouraged by Shalamov's story. But in the end, when the discussion became too heated or hit too close to home, they shut down and no longer participated. Had the conversation at least opened up some small pathway toward insight or self-discovery? I speculate that it did, based on my years of working with this population and observing how even a brief interchange on a subject that strikes a deep chord within the residents can become a powerful impetus to change. And it is not uncommon for students in Books Behind Bars to go through an entire semester unsure of whether they are making any impact, only to discover through a few heart-felt words or an unsolicited letter of appreciation offered by the residents on the final day that their time spent with the residents mattered.

Unfortunately, Lisa and Jennifer had even less to go on. During our full-class debriefing after the final session at Beaumont, many UVa students reflected wistfully on the surprisingly deep bonds formed between them and the residents in such a short amount of time, and they expressed sadness that those relationships had to come to an end. Some students reminisced about the moving speeches made by a number of residents on the final day. But while the class was basking in the sad-sweet glow of that final, poignant day at Beaumont, Lisa and Jennifer were conspicuously quiet. Lisa raised her hand sheepishly. 'I didn't have that experience at all,' she said, and went on to describe how Edward was the only resident at the final meeting, with James having left a few weeks earlier. Edward told Lisa and Jennifer nonchalantly, as if reporting on the weather, that his prediction at the beginning of the semester had turned out to be correct: the program had been a complete waste of time. Lisa's voice began to quiver. 'I loved my residents,' she told the class, trying to hold back tears, 'and I don't know if we made any difference.' A long, uncomfortable silence ensued.

The question - am I making any difference? - is at the forefront of the minds of those who work with traumatized youth populations. The facts themselves make it difficult to answer that question in the affirmative. There were about 147,000 youths 
in corrections nationwide in 2011, according to the Justice Policy Institute. ${ }^{3}$ The average yearly cost to rehabilitate one juvenile offender in 2008 was $\$ 66,000$ to $\$ 88,000$, according to statistics from the American Correctional Association and Annie E. Casey Foundation report. ${ }^{4}$ This amounts to more than $\$ 9.7$ billion per year, conservatively speaking. Yet, despite the billions of dollars poured into correctional and other rehabilitation efforts, 75 percent of these offenders will be rearrested within three years, and half or more convicted of a new offense. So whether our system is rehabilitating these youths is questionable at best. Perhaps this explains why so many people who work with troubled youth eventually fall prey to cynicism or suffer from burnout.

Students in Books Behind Bars receive first-hand exposure to those challenges Lisa and Jennifer perhaps more than most. It's one thing to enter wide-eyed into a class like Books Behind Bars and find your high hopes met by smiles, poignant moments of connection and gestures of appreciation, or, in the absence of these things, at least to find out in the end that the residents you worked with actually did get something out of the experience. But it's another matter altogether when your every sincere effort and intention are met with dismissal and hostility, when you discover that the young men you cared about and on whose behalf you worked so hard could seem to care less about your presence. What does one do then? Put up a steely armor of self-protective cynicism? Persist in one's quixotic insistence that the world is the way you'd like it be, rather than the way it is? Just give up? Each of these tried and true paths offers a tempting escape from the hard business of living and leading. But they weren't Lisa's answer. Her answer - the right one, in my view - was to feel deeply the frustration that comes with trying and, in her estimation, failing, to effect positive change in the world, and then recommitting to doing just that.

In her final course essay, significantly titled 'Authenticity and Exile,' Lisa wrote about the deeper motivations that drew her to the class, rounding out the picture of her I had gleaned from her application and other course work. She had always felt like an exile in her social circle and in her own family, who pressured her into a life she didn't want for herself. She felt shame that so many of her decisions - her choice to defy the family tradition of going to a faith-based institution, her selection of majors, of boyfriends, of lifestyle - were a rejection of her past. Lisa came to Books Behind Bars, then, not just with a set of academic goals, but with a personal mission, as well: to make sense of her feelings of exile while bearing witness to the experiences of those who were trying to do the same. It was not lost on Lisa that she was engaged in this quest as a successful young woman attending one of the country's most privileged universities. In fact, this contradiction only increased her sense of responsibility to know the residents 'for who they are, not for their sentences,' and to see them in a more broad-minded, open-hearted way than Lisa felt she was seen by those closest to her. This explains why she felt so powerfully drawn to the youth at Beaumont, just as she'd been attracted to the exiles in Rwanda and Israel before them, and why her failure to connect with the Beaumont residents was personally disturbing to her. She was being rejected by the very people with whom she thought she

3. Justice Policy Institute, 'Sticker Shock: Calculating the Full Price Tag for Youth Incarceration,' December 2014. Found online at http://www.justicepolicy.org/research/8477.

4. The Annie E. Casey Foundation, 'No Place for Kids: The Case for Reducing Juvenile Incarceration,' October, 2011. Found online at: http://www.aecf.org/resources/no-place-forkids-full-report/. 
identified and whom she most wanted to help. She tried to make sense of this hard truth in her essay:

Some people might reject you, and despite your efforts to give them your best, to give them exactly what you want yourself, they need something different. Something you can't give them. You see, I just want someone to bear witness to my experiences. To find me in my exile and tell me they've trodden those lonely roads too, in their own way.

But that wasn't what Edward and James wanted from me. ... What hurt the most was having them not only reject that witness, my continued effort to show up and be present, but for them to tell me my offering was 'petty' and futile. Nonetheless, I understand where Edward and James were coming from when they said I cannot understand their pain. I can't. Neither can they understand the depth of the sorrow I feel exiled from my family, community, and heritage, even if by my own doing.

What matters, however, is that I tried: I did show up each week to try and bear witness to their experiences, their own confrontation with exile, and tell them they were heard. It was difficult to have those attempts demeaned and belittled, because all I have wanted for so long is for someone to bear witness to mine. ...

I have learned from Books Behind Bars that it is critical to wade through experiences, with my pores wide open, to be grateful for everything I see and feel. Even if it wasn't quite what I expected.

That's a hard lesson for a college student to learn. Like other students in Books Behind Bars, Lisa gained a deep, personal knowledge of just how difficult and deeply rooted the problem of youth incarceration is in our country, and why so many people both within and outside of the system have despaired of the possibility of finding any solution to it. Yet Lisa learned something else, too: the importance of embracing pain and adversity and allowing them to galvanize her to continue striving toward her ideals, no matter how elusive they may appear to be.

As the Russians understand so well, sorrow and frustration are often the price we have to pay for a fully engaged life - one lived with our 'pores wide open,' as Lisa aptly put it in her essay. To see reality for what it is and yet to still have the courage to hold onto one's ideals; to be thwarted in your efforts to make a difference in the world and yet to still believe in the possibility of social change and to work toward it: that is the message of human resilience that recurs throughout the works of the great Russian writers. And it is one of the most important lessons Lisa and the other UVa students as well as the incarcerated youth participants take away from Books Behind Bars. They discover, not in the abstract but from personal experience, the wisdom contained in Tolstoy's words: 'Man is flowing. In him there are all possibilities: he was stupid, now he is clever; he was evil, now he is good, and the other way around. In this is the greatness of man. ${ }^{5}$

5. Leo Tolstoy, Polnoe sobranie sochinenii v 90-kh tomakh [The Complete Collected Works in 90 vols], vol. 5., p. 62. 


\section{REFERENCES}

Dostoevsky, F. (1861 [2013]), Notes from the House of the Dead, Grand Rapids, MI: Eerdmans.

Henderson, N. and Milstein, M.M. (1996), Resiliency in Schools: Making it Happen for Students and Educators (Thousand Oaks, CA: Corwin Press).

Intrator, Sam M. and Scribner, M. (2007), Leading from Within: Poetry that Sustains the Courage to Lead (San Francisco: Jossey-Bass, pp. 131-154).

Ledesma, J. (2014), 'Conceptual Frameworks and Research Models on Resiliency in Leadership,' Sage Open, July-September, 1-8.

Masten, A.S. (2001), 'Defining Resilience,' American Psychologist, 56, 227-238.

Masten, A.S., Best, K.M., and Garmezy, N. (1990), 'Resilience and Development: Contributions from the Study of Children who Overcome Adversity,' Development and Psychopathology, 2, $425-444$.

Patterson, J. and Patterson, J.H. (2001), 'Resilience in the Face of Imposed Changes,' Principal Leadership, 1(6), 50-55.

Rutter, M. (1990), 'Psychosocial Resilience and Protective Mechanisms,' in J. Rolf, A. Masten, D. Cicchetti, K. Neuchterlein, and S. Weintraub (eds), Risk and Protective Factors in the Development of Psychopathology (New York: Cambridge University Press, pp. 181-214).

Shalamov, Varlam (1982 [1995]), 'My First Tooth,' in Varlam Shalamov, Kolyma Tales, trans. John Glad (London and New York: Penguin, pp. 380-387).

Snyder, S. (2013), Leadership and the Art of Struggle: How Great Leaders Grow Through Challenge and Adversity (San Francisco: Berrett-Koehler). 